BBA 53I3I

\title{
Formation of dehydroepiandrosterone sulphate by previable human foetuser
}

The steroid pattern of cord blood is characterized by a high concentration of dehydroepiandrosterone sulphate and $I 6 \alpha$-hydroxydehydroepiandrosterone sulphate (refs. 2-4). These compounds are the principal precursors of the large amounts of oestrogens formed by the placenta $\mathbf{a}^{\mathbf{5}, \mathbf{6}}$. To elucidate the pathway of dehydroepiandrosterone sulphate formation in the foeto-placental unit, we perfused mid-term placentas in situ with labelled I $7 \alpha$-hydroxypregnenolone. The perfused placentas were not capable of removing the steroid side-chain?. This suggested that the sidechain cleavage occurs in the foetal rather than placental compartment. The following study was therefore undertaken.

Two male foetuses ( 18 and 20 weeks) were obtained following hysterotomy and perfused for 60 min with $25 \mu \mathrm{C}$ of $\left[7 \alpha^{-3} \mathrm{H}\right] \mathrm{I} 7 \alpha$-hydroxypregnenolone (batch $5 \mathrm{I}-224-5 \mathrm{a}$, with a specific activity of $0.4 \mu \mathrm{C} / \mu \mathrm{g}$, New England Nuclear Corp., Boston, Mass.). The purification of this compound was described previously? ${ }^{7}$. Upon completion of the perfusions, the perfusates and various foetal organs were extracted separately, using previously described methods ${ }^{8,9}$. The distribution of ether-soluble (unconjugated) and water-soluble (conjugated) radioactive material recovered from the various sources is shown in Table I. In the two cases, 85 and $92.6 \%$ of the perfused radioactivity was recovered. The bulk of the radioactive material recovered from all sources except the adrenals was in an unconjugated form.

\section{TABLE I}

DISTRIBUTION OF THE ETHER-SOLUBLE (UNCONJUGATED) AND WATER-SOLUBLE (CONJUGATED) RADIOACTIVE MATERIAL RECOVERED FROM THE VARIOUS TISSUES AND PERFUSATES FOLLOWING THE PERFUSION OF TWO PREVIABLE HUMAN FOETUSES WITH $25 \mu \mathrm{C}$ oF ${ }^{3} \mathrm{H}$-LABELLED I $7 \alpha$-HYDROXYPREGNENOLONE

Figures are expressed as percentage of administered material.

\begin{tabular}{|c|c|c|c|c|}
\hline & \multicolumn{2}{|c|}{ Expt, $A$} & \multicolumn{2}{|c|}{$\operatorname{Expt.B}$} \\
\hline & $\overline{\text { Ether }}$ & Water & Ether & Water \\
\hline Adrenals & 0.2 & 0.8 & 0.3 & 0.3 \\
\hline Liver & 5.2 & 0.8 & 14.0 & 5.0 \\
\hline Residual foetal tissues & I9.0 & 2.0 & 25.0 & 3.0 \\
\hline Perfusate & 53.0 & 4.0 & 41.0 & 4.0 \\
\hline Total & \multicolumn{2}{|c|}{85.0} & \multicolumn{2}{|c|}{92.6} \\
\hline
\end{tabular}

The following trivial names are used: pregnenolone: $3 \beta$-hydroxypregn-5-en-2o-one; pregnenolone sulphate : 20 -oxopregn-5-en- $3 \beta$-yl sulphate; $17 \alpha$-hydroxypregnenolone: $3 \beta$, I $7 \alpha$-dihydroxypregn-5en-2o-one; I $7 \alpha$-hydroxypregnenolone sulphate: I $7 \alpha$-hydroxypregn- 5 -en-2o-one- $3 \beta$-yl sulphate; dehydroepiandrosterone: $3 \beta$-hydroxyandrost-5-en-I 7 -one; dehydroepiandrosterone sulphate: 17 oxoandrost-5-en-3 $\beta$-yl sulphate; I $6 \alpha$-hydroxydehydroepiandrosterone sulphate: I $6 \alpha$-hydroxyandrost-5-en-I 7 -one- $3 \beta$-yl sulphate.

The following solvent systems were used : System A: isooctane-ethyl acetate- $n$-butanol-methanolI $\mathrm{M} \mathrm{NH} \mathrm{N}_{4} \mathrm{OH}(20: 40: 8: 20: 30)$; System $\mathrm{B}$ : isooctane-chloroform- $n$-butanol-methanol-0.3 M pyridinium sulphate-pyridine (40:20:8:20:19:1); System C: butanol-butyl ether-ammonium hydroxide-water $(5: 5: 1: 9)$ : System D: ligroin-benzene--methanol-water $(66: 33: 80: 20)$.

* A preliminary report was presented at the 6th Pan American Congress of Endocrinology, Mexico, October, 1965 (ref. I). 
The conjugated material obtained from the various sources was subjected to column partition chromatography in System A (ref. Io). The dehydroepiandrosterone sulphate-like radioactive material was then subjected to paper partition chromatography with authentic dehydroepiandrosterone sulphate in System C, eluted and solvolysed "1. The liberated material was subjected to paper partition chromatography with carrier dehydroepiandrosterone in System D, after which the identity of this material (with dehydroepiandrosterone) was established by reverse isotope dilution (Table II).

Chromatography of the dehydroepiandrosterone sulphate-like material in System $B$ revealed the presence of another peak with the partition characteristics of I $7 \alpha$-hydroxypregnenolone sulphate. This material was chromatographed with authentic $17 \alpha$-hydroxypregnenolone sulphate in System $C$. The $I 7 \alpha$-hydroxypregnenolone sulphate-like radioactive material was then solvolysed, the liberated steroid and carrier chromatographed in System D, mixed with additional carrier and crystallized to constant specific activity (Table II). Neither dehydroepiandrosterone sulphate nor r $7 x$-hydroxypregnenolone sulphate could be isolated from the liver.

TABLE II

CRYSTALLIZATION TO CONSTANT SPECIFIC ACTIVITY (disint./min per mg) OF DEHYDROEPIANDROSTERONE AND OF I $7 \alpha$-HYDROXYPREGNENOLONE ISOLATED IN THE FORM OF DEHYDROEPIANDROSTERONE SULPHATE AND I $7 \alpha$-HYDROXYPREGNENOLONE-3-SULPHATE, RESPECTIVELY, FROM PREVIABLE FOEYUSES PERFUSED WITH ${ }^{3} \mathrm{H}$-LABELLED $17 \alpha$-FY

Solvents used: a, methanol; $b$, methanol-ether; $c$, ethanol; $d$, ligroin.

\begin{tabular}{|c|c|c|c|c|c|c|}
\hline \multirow[t]{2}{*}{ Sounce } & \multicolumn{3}{|c|}{ Dehydroepiandrosterone } & \multicolumn{3}{|c|}{ I7 $\alpha$-Hydroxypregnenolone } \\
\hline & Solveni & Crystals & $\begin{array}{l}\text { Mother } \\
\text { liquor }\end{array}$ & Solvent & Cyystals & $\begin{array}{l}\text { Mother } \\
\text { liquor }\end{array}$ \\
\hline \multirow[t]{3}{*}{ Adrenals } & a & 575 & 740 & $\mathrm{a}$ & 3 I5 & 300 \\
\hline & c & 590 & 610 & $\mathrm{~d}$ & $295^{*}$ & \\
\hline & $\mathrm{d}$ & $5^{8} 5^{*}$ & & & & \\
\hline \multirow[t]{3}{*}{ Residual foetal tissues } & $a$ & $0.86 * *$ & 0.93 & a & 610 & 3070 \\
\hline & $\mathrm{c}$ & 0.85 & 0.95 & $\mathrm{c}$ & $4 I_{5}$ & $74 \circ$ \\
\hline & $\mathrm{a}$ & 0.82 & $0.8 \mathrm{I}$ & $\mathrm{a}$ & 400 & $43^{\circ}$ \\
\hline \multirow[t]{3}{*}{ Perfusate } & a. & 3690 & 4050 & & & \\
\hline & $\mathrm{b}$ & 3630 & & & & \\
\hline & $c$ & $375^{\circ}$ & 3710 & & & \\
\hline
\end{tabular}

* Crystallized as the acetate.

** Crystallized to constant isotopic ratio following the addition of authentic $\left[4^{-14} \mathrm{C}\right] \mathrm{dehy} d \mathrm{ro}-$ epiandrosterone.

These data establish the capacity of the mid-term human foetus to remove the side-chain of $17 \alpha$-hydroxypregnenolone by converting this compound into dehydroepiandrosterone sulphate. The isolation of dehydroepiandrosterone sulphate from the perfusate indicates that the dehydroepiandrosterone sulphate formed is secreted by the foetus into the umbilical circulation. It appears from the data that the adrenal is an important site of side-chain cleavage for $\mathrm{C}_{21}$ steroids with a $3 \beta-\mathrm{HO}-\Delta^{5}$ structure. This seems to be in contrast to the fate of $C_{21}$ steroids with an $\alpha, \beta$-unsaturated 3-oxo group $^{12}$. Whether other foetal tissues (e.g. the testicles) are also capable of removing the steroid side-chain in vivo remains to be studied.

Since pregnenolone sulphate is present in the umbilical circulation in substantial quantities ${ }^{13-15}$ and was shown to be hydrolysed by mid-term placentas perfused 
in situ $^{16}$ and, furthermore, since pregnenolone is converted by perfused previable fnetuses into $17 \alpha$-hydroxypregnenolone ${ }^{17}$, the reactions leading to the formation of dehydroepiandrosterone sulphate in the human foetus at midpregnancy can be summarized as shown in Fig. I. It remains to be established whether sulphurylation of I $7 \propto$-hydroxypregnenolone precedes the removal of the side-chain.

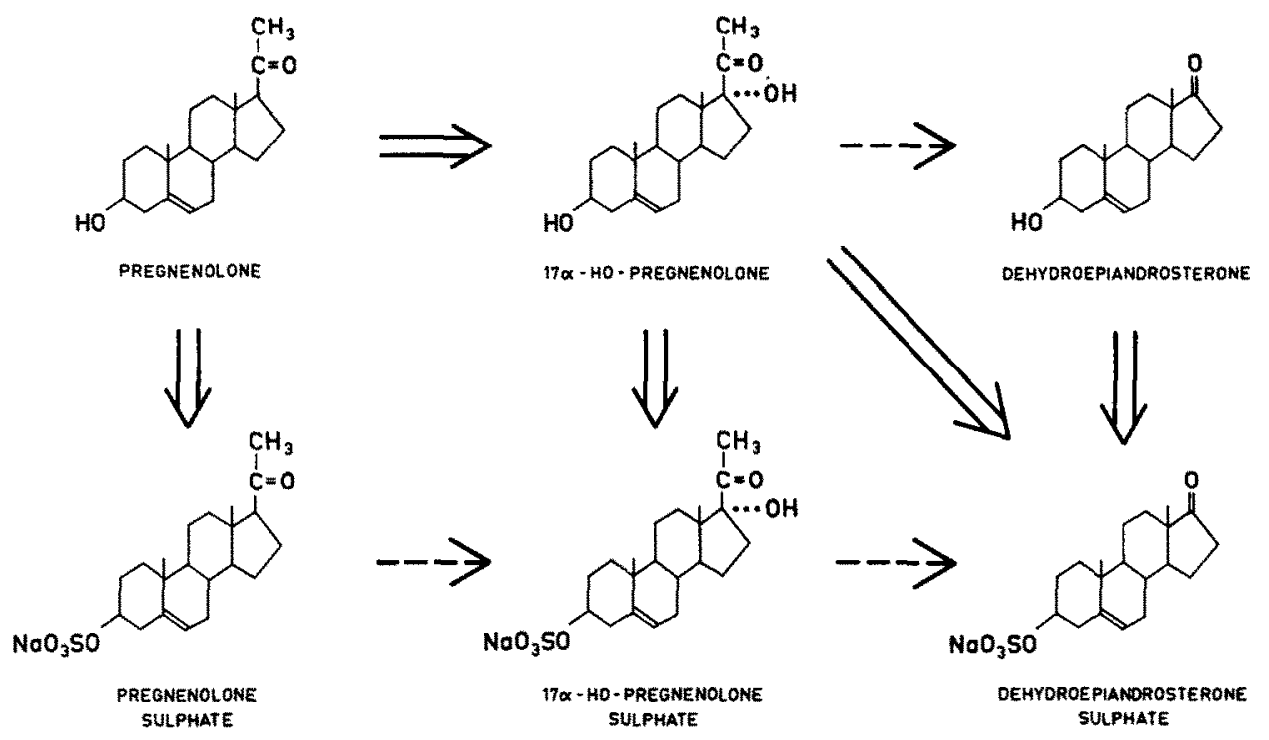

Fig. $x$. Concept of the formation of dehydroepiandrosterone sulphate by the previable human foetus. Solid arrows: established pathways. Dotted arrows: postulated but not yet proven reactions.

It is of interest that cholesterol was shown to be converted into pregnenolone by the human placenta ${ }^{18}$ but not by the foetus ${ }^{17}$. It seems possible therefore that the cleavage of the cholesterol side-chain takes place in the placental and that of the steroid side-chain in the foetal compartment.

The expenses of this investigation were defrayed by a Research Grant from the Ford Foundation, by Grant I9P-703-02A from the Medical Research Conncil of Sweden, by the University of Washington Graduate School Initiative No. $17 \mathrm{x}$ and by U.S. Public Health Service Grants HD or $85 \mathrm{I}-03$ and HD 1776 . One of the authors (R.B.J.) is a Josiah Macy, Jr. Foundation Fellow.

Department of Obstetrics and Gynecology, University of Wash-

Ronald J. Pion ington, School of Medicine, Seattle, Wash. (U.S.A.)

Department of Obstetrics and Gynecology, University of Michigan, Medical Center, Ann Arbor, Mich. (U.S.A.)

ROBERT B. JAFFE

Hormone Laboratory, Department of Women's Diseases,

Nils Wrovist

Karolinska sjukhusel, Slockholm (Stoeden)

Egon DiczFalusy 
I R. J. Pion, R. B. Jaffe and E. Diczfalusy, Proc. 6th Pan Am. Congr. Endocrinol., Mexico, 1965. Excerpta Medica Congress Series No. 99, London, 1965, Abstract No. 409.

2 W. E. Easterling, Jr., H. H. Simmer, W. J. Dignam, M. V. Frankland and F. Naftolin, Steroids, 8 (I966) I 57.

3 A. ColÁs, W. L. Heinrichs and H. J. Tatum, Steroids, 3 (I964) 4 I 7.

4 H. G. Magendantz and K. J. Ryan, J. Clin. Endocrinol. Metab., 25 (1965) I 55.

5 E. Bolte, S. Mancuso, G. Eriksson, N. Wigvist and E. Diczfalusy, Acta Endocrinol., 45 (1964) 535 .

6 S. Dell'Acgua, S. Mancuso, G. Eriksson, J. L. Ruse, S. Solomon and E. Diczfalusy, Acta Endocrinol., in the press.

7 R. J. Pion, R. B. Jaffe, G. Eriksson, N. Wigvist and E. Diczfalusy, Acta Endocrinol., 48 (1965) 234 .

8 G. Mikhail, N. Wiqvist and E. Diczfalusy, Acta Endocrinol., 42 (I963) 519.

9 J. Schwfis, M. Govafirts-Vinfitsky, N. Wigvist and E. Diczfaltisy, Acta Endocrinol., $5^{\circ}$ (1965) 597.

io H. I. Calvin, K. D. Roberts, C. Weiss, L. Bandi, J. J. Cos and S. Lieberman, Anal. Biochem., I 5 (I966) 426.

i I S. Burstein and S. Lieberman, J. Am. Chem. Soc., 8o (I958) 5235.

12 C. E. Bird, N. Wigvist, E. Diczfalusy and S. Solomon, J. Clin. Endocrinol. Metab., 26 (I966) I I 44 .

i3 K. J. Ryan, R. Meigs and Z. Petro, Am. J. Obstet. Gynecol., 96 (1966) 676.

I 4 S. H. Conrad, R. J. PION and J. D. Kitchin, J. Clin. Endocrinol. Metab., 27 (1967) I I4.

I5 W. R. EBerlein, J. Clin. Endocrinol. Metab., 25 (I965) i IOI.

I6 R. Palmer, G. ERIksson, N. Wigvist and E. Diczfalusy, Acta Endocrinol., 52 (1966) 598.

I 7 S. Solomon, Rec. Progr. Hormone Res., in the press.

i 8 R. B. Jaffe and E. P. Peterson, Steroids, 8 (1966) 695.

Received March 8th, 1967

Biochim. Biophys. Acta, I 37 (1967) 584-587 